\title{
Diagnostic and therapeutic odyssey of two patients with compound heterozygous leptin receptor deficiency
}

\author{
Stefanie Zorn, Julia von Schnurbein, Katja Kohlsdorf, Christian Denzer and Martin Wabitsch ${ }^{*}$ (D)
}

\begin{abstract}
Background: Rare genetic variations in the leptin-melanocortin signalling pathway can severely impair appetite regulation and cause extreme obesity in early childhood.

Case presentation: Our case reports describe the diagnostic and therapeutic procedures in a girl as well as in a non-related boy of non-consanguineous, German parents with severe early-onset obesity, pronounced hyperphagia, and permanent food-seeking behaviour. Excessive weight gain within the first year of life initiated extensive diagnostics without finding a causal diagnosis. Furthermore, a wide range of intensive, interdisciplinary, and behavioural therapies for weight control were unsuccessful. Prior to bariatric surgery, the 18-year-old girl and the 14-year-old boy reached a BMl of $67.7 \mathrm{~kg} / \mathrm{m}^{2}$ and $55.2 \mathrm{~kg} / \mathrm{m}^{2}$, respectively. However, even surgical outcomes were unsatisfactory. A subsequently initiated genetic analysis including sequencing of the leptin receptor gene revealed compound heterozygous variants as a cause of the severe early-onset obesity in both patients (c.2598-3 2607delTAGAATGAAAAAG and c.2227 T>C; c.1874G >A and c.2051A>C). Both patients were enrolled in the clinical study RM-493-015 and treated with melanocortin receptor agonist setmelanotide. Currently, they are still on setmelanotide treatment in the extension trial RM-493-022.
\end{abstract}

Conclusion: Our case report illustrates the urgent necessity of early genetic diagnostics in children with severe early-onset obesity to avoid frustrating and potentially damaging therapies. Thus, genetic examination should precede bariatric surgery. In the future, several pharmacological therapies will be available for some forms of monogenetic obesity.

Keywords: Leptin receptor, Genetics, Monogenetic obesity, Early-onset obesity, Hyperphagia

\section{Background}

Obesity in children and adolescents is associated with an increased risk for serious health consequences and with an impaired psychological and social development $[1,2]$. Severe, early-onset obesity can be due to disease-causing genetic variations. These can interrupt the leptinmelanocortin signalling pathway and impair the regulation of hunger and satiety [3-5]. There is growing knowledge about the effects of rare genetic variations on body

\footnotetext{
*Correspondence: martin.wabitsch@uniklinik-ulm.de

Center for Rare Endocrine Diseases, Division of Paediatric Endocrinology and

Diabetes, Department of Paediatrics and Adolescent Medicine, Ulm

University Medical Centre, 89075 Ulm, Germany
}

weight and new pharmacological treatments for children with monogenic obesity, e.g. leptin receptor deficiency will become available. It is therefore important to identify monogenic obesity early in life in order to prevent subsequent secondary damages [6-8].

\section{Case presentations \\ Patient 1}

The girl is the second child of German, nonconsanguineous parents. She was a newborn of 39 weeks of gestational age, weighted $3690 \mathrm{~g}$, and had a birth length of $54 \mathrm{~cm}$. Already in the first weeks of her life, the girl showed signs of hyperphagia by crying regularly

\section{Springer Open}

(c) The Author(s). 2020 Open Access This article is licensed under a Creative Commons Attribution 4.0 International License, which permits use, sharing, adaptation, distribution and reproduction in any medium or format, as long as you give appropriate credit to the original author(s) and the source, provide a link to the Creative Commons licence, and indicate if changes were made. The images or other third party material in this article are included in the article's Creative Commons licence, unless indicated otherwise in a credit line to the material. If material is not included in the article's Creative Commons licence and your intended use is not permitted by statutory regulation or exceeds the permitted use, you will need to obtain permission directly from the copyright holder. To view a copy of this licence, visit http://creativecommons.org/licenses/by/4.0/. 
after the end of a meal and only calmed down after further food intake. A perceptible feeling of satiety did not occur even after extensive food intake. Excessive weight gain within the first year of life led to a body weight of $18 \mathrm{~kg}$ (BMI $28.1 \mathrm{~kg} / \mathrm{m}^{2}$, BMI SDS 6.2) (Fig. 1a). Despite numerous diagnostic examinations, no causal diagnosis could be found for the extreme early-onset obesity (Table 1). The persistent desire for food and the continuous weight gain (Fig. 1a) played a major role in daily family life and massively distressed the girl and her family. Negative social experiences at school (e.g. bullying and teasing) led to social isolation. Intensive, interdisciplinary, behavioural treatments to reduce weight were unsuccessful in the long term (Table 2). Repeated setbacks after frustrating weight loss attempts caused a deep depression with suicidal thoughts, but no drug treatment was required. After exhaustion of common therapeutic approaches, she finally decided to undergo bariatric surgery at the age of 18 years. At this time, she weighed $188 \mathrm{~kg}$ (BMI $67.7 \mathrm{~kg} / \mathrm{m}^{2}$ ). As a result, she lost $38 \mathrm{~kg}$ within 1 year followed by rapid weight regain of $22 \mathrm{~kg}$ within 8 months (Fig. 1). However, hypogonadotropic hypogonadism diagnosed at the age of 17 resolved one year after bariatric surgery.

\section{Patient 2}

The boy was born with a gestational age of 40 weeks, a birth weight of $3320 \mathrm{~g}$, and a birth length of $50 \mathrm{~cm}$. He is the second child from healthy, non-consanguineous parents of German-Polish origin. Since the first year of life, the boy had permanent hunger, followed by excessive weight gain. Consequently, he weighed $25 \mathrm{~kg}$ at the age of 2 years (BMI $33.0 \mathrm{~kg} / \mathrm{m}^{2}$, BMI SDS 5.5). His extreme body weight restricted his mobility and delayed ageappropriate gross motor development (Fig. 1b). Therefore, comprehensive diagnostics were performed to find the cause of the early-onset obesity. However, no causal diagnosis could be found (Table 1). At the age of 8 years, short stature and growth hormone deficiency were diagnosed. During 3 years of growth hormone treatment, he caught up to a height within normal range from 1.24 to $1.55 \mathrm{~m}$ but he also gained weight from 42.5 to $101.5 \mathrm{~kg}$. He attempted a number of conservative treatment approaches to reduce weight without any appreciable success (Table 2). He behaved dissocially and aggressively towards peers and adults, partly in response to negative social experiences, accusations, and teasing. The familiar atmosphere was extremely tense due to his permanent demand for food, his extreme obesity, and the lack of a medical explanation. Finally, he developed a deep depression with suicidal thoughts as a result of the immense physical, mental, familiar, and social stresses. However, he required no drugs to treat depression. At the age of 14 years and a body weight of $154 \mathrm{~kg}$ (BMI $55.2 \mathrm{~kg} / \mathrm{m}^{2}$ ), he received gastric banding which helped him to lose $16 \mathrm{~kg}$ within one year. In the same year as bariatric surgery, he obtained the diagnosis of hypogonadotropic hypogonadism, which could no longer be detected 4 years after gastric banding. In total, he lost 49 $\mathrm{kg}$ within 8 years after gastric banding. This weight reduction seems to be impressive, but it should be noted that the follow-up process after gastric banding was associated with severe complications. Hence, he suffered from recurrent episodes of severe epigastric pains, nausea, vomiting, and diarrhoea. This could also have contributed to the impressive weight reduction. In total, the complications of the gastric banding lead to a deterioration in quality of life. At the age of 25 years, the gastric band had to be removed due to gastric band migration with severe epigastric pains, nausea, and vomiting (Table 2).

\section{Findings}

At the time of diagnosis, patient 1 is 20 years old, lives on her own, and is completing a training. She weighs $172 \mathrm{~kg}$ and has numerous obesity-associated comorbidities (dyslipidaemia, hyperinsulinaemia, hepatic steatosis, hyperuricaemia, and a sleep apnea syndrome). Furthermore, she has a hypochromic microcytic anaemia due to iron deficiency and vitamin D deficiency.
(A)

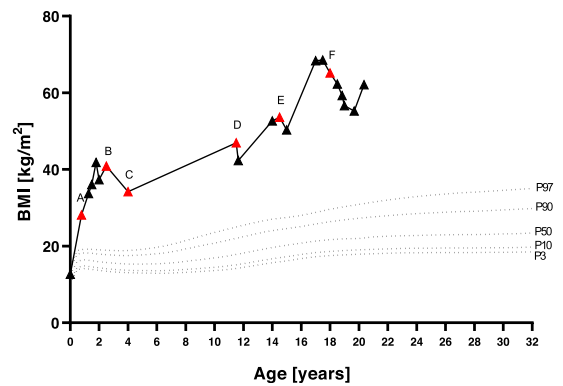

(B)

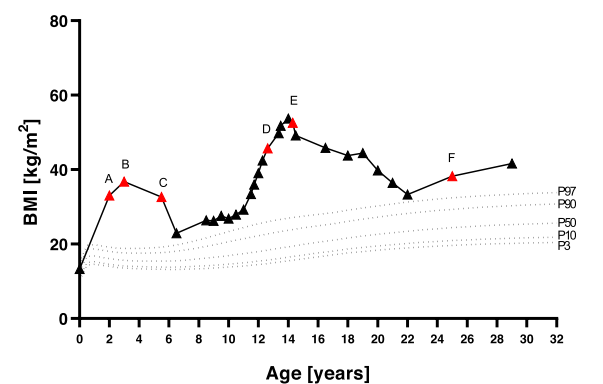

Fig. 1 Body mass index (BMI) trajectories from birth to diagnosis of leptin receptor deficiency in patient 1 (a) and patient 2 (b). Previous therapy approaches to treat obesity are marked in red (A-F) and can be seen in Table 2 
Table 1 Chronology of diagnostic examinations performed in the two patients to exclude endocrine and syndromic diseases causing severe, early-onset obesity

\begin{tabular}{|c|c|c|c|}
\hline & Age, year $(y)$ month $(\mathrm{m})$ & Suspected diagnoses & Methods \\
\hline \multirow[t]{15}{*}{ Patient 1} & 0 y $9 \mathrm{~m}$ & Hypercortisolism & Cortisol profile and dexamethasone suppression test \\
\hline & & Hypothyroidism & Thyrotropin-releasing hormone stimulation test \\
\hline & & Growth hormone deficiency & Insulin hypoglycaemia test and radiography \\
\hline & & Brain tumour/brain malformation & Sonography \\
\hline & 1 y 10 m & Prader-Willi syndrome & MS-MLPA \\
\hline & & Chromosome aberrations & Chromosome analysis \\
\hline & & Congenital leptin deficiency & Leptin ELISA \\
\hline & 2 y $6 \mathrm{~m}$ & Brain tumour/brain malformation & MRI \\
\hline & & Pituitary tumour & MRI \\
\hline & & Hypercortisolism & Urinary cortisol profile \\
\hline & & Disorder of the adipocyte differentiation & In vitro functional examination \\
\hline & & Adrenal insufficiency & Adrenocorticotropic hormone test \\
\hline & & Adrenal gland tumour & $C T$ \\
\hline & & Congenital leptin deficiency & Leptin ELISA \\
\hline & & Prohormone convertase deficiency & Oral glucose tolerance test, proinsulin ELISA \\
\hline \multirow[t]{18}{*}{ Patient 2} & 1 y $11 \mathrm{~m}$ & Hypercortisolism & Cortisol profile \\
\hline & & Hypothyroidism & Laboratory \\
\hline & & Chromosome aberrations & Chromosome analysis \\
\hline & & Insulinoma & Blood glucose profile \\
\hline & & Prader-Willi syndrome & MS-MLPA \\
\hline & & Pseudohypoparathyroidism & Laboratory values and radiography \\
\hline & & Brain tumour/brain malformation & $C T$ \\
\hline & & Glycogenosis type I & Clinical examinations \\
\hline & 2 y $9 \mathrm{~m}$ & Brain tumour/brain malformation & MRI \\
\hline & & Hypothalamus tumour & MRI \\
\hline & & Prader-Willi syndrome & MS-MLPA \\
\hline & 5 y $6 \mathrm{~m}$ & Eating disorders & Psychological examinations \\
\hline & 8 y 11 m & Growth hormone deficiency & L-Arginine and insulin-tolerance tests \\
\hline & 9 y 3 m & Anterior pituitary insufficiency & $\begin{array}{l}\text { Corticotropin-releasing hormone stimulation test } \\
\text { and thyrotropin-releasing hormone stimulation test }\end{array}$ \\
\hline & & Brain tumour/brain malformation & MRI \\
\hline & 11 y $9 \mathrm{~m}$ & Pituitary tumour & MRI \\
\hline & 12 y 2 m & Disorder of the hypothalamic-pituitary-adrenal axis & Combined pituitary stimulation test \\
\hline & & Adrenal insufficiency & Adrenocorticotropin stimulation test \\
\hline
\end{tabular}

CT computer tomography, ELISA enzyme-linked immunosorbent assay, MS-MLPA methylation-specific multiplex ligation-dependent probe amplification, MRI magnetic resonance imaging

Patient 2 is 29 years old, is unemployed, and lives with his girlfriend in a shared apartment. He is holding a disabled person's pass with a degree of disability of $60 \%$. He weighs $120.5 \mathrm{~kg} 4$ years after gastric band removal. Apart from obesity, he suffers from bronchial asthma, atopic dermatitis, and episodes of recurrent diarrhoea and vomiting.

Selected clinical and laboratory findings in the two patients are presented in Table 3.

\section{Diagnosis}

Numerous endocrinological and syndromic diseases known to cause early-onset obesity were excluded in both patients (Tables 1 and 2). Moreover, it seemed inappropriate to attribute the extreme early-onset obesity solely to an unfavourable lifestyle. Based on recent findings on monogenetic causes of obesity, molecular genetic examinations were initiated. For molecular genetic diagnostic, the genomic DNA of both patients was 
Table 2 Measures for treatment of obesity from birth to the age at diagnosis of leptin receptor deficiency in the two patients

\begin{tabular}{|c|c|c|c|}
\hline & $\begin{array}{l}\text { Age, year }(y) \\
\text { month }(\mathrm{m})\end{array}$ & Measures for treatment of obesity & Impact on weight \\
\hline \multirow[t]{10}{*}{ Patient 1} & Ongoing & Restrictive food intake and motivation for physical activity & None \\
\hline & 0 y $9 \mathrm{~m}$ & $\begin{array}{l}9 \text { days stay in a paediatric clinic with caloric restriction } \\
\text { to } 600 \mathrm{kcal} \text { per day }{ }^{\mathrm{a}}\end{array}$ & None \\
\hline & $3 y$ & $\begin{array}{l}21 \text { days stay in a specialised clinic for metabolic disorders } \\
\text { and Prader-Willi syndrome }\end{array}$ & None \\
\hline & 4 y 2 m & $\begin{array}{l}14 \text { days stay in a specialised clinic for Tomatis Listening } \\
\text { Therapy }^{c}\end{array}$ & None \\
\hline & 10 y 4 m & 2 years outpatient psychotherapy for mother and child & None \\
\hline & 11 y $5 \mathrm{~m}$ & 6 weeks stay in a rehabilitation clinic focusing obesity ${ }^{d}$ & $-10.7 \mathrm{~kg}(-9.86 \%)$, followed by weight regain \\
\hline & 14 y $7 \mathrm{~m}$ & $\begin{array}{l}6 \text { months stay in a rehabilitation clinic with obesity } \\
\text { long-term therapy }\end{array}$ & $\begin{array}{l}-15.6 \mathrm{~kg}(-6.41 \%), \text { followed by } 9.3 \mathrm{~kg} \text { weight } \\
\text { regain within } 1 \text { month }\end{array}$ \\
\hline & 18 y $1 \mathrm{~m}$ & $\begin{array}{l}\text { Leaving the parental home and moving into an assisted } \\
\text { living community }\end{array}$ & $-8 \mathrm{~kg}(+4.26 \%)$ \\
\hline & 18 y 3 m & 2 years outpatient psychotherapy & None \\
\hline & 18 y $4 \mathrm{~m}$ & Bariatric surgery: sleeve gastrectomy ${ }^{f}$ & $\begin{array}{l}-38 \mathrm{~kg}(-20.13 \%) \text {, followed by weight regain } \\
\text { (overall weight reduction, } 16 \mathrm{~kg}(-8.47 \%))\end{array}$ \\
\hline \multirow[t]{12}{*}{ Patient 2} & Ongoing & Restrictive food intake and motivation for physical activity & None \\
\hline & 1 y $11 \mathrm{~m}$ & $\begin{array}{l}15 \text { days stay in a paediatric clinic with daily } 800 \mathrm{kcal} \\
\text { caloric restriction }\end{array}$ & None \\
\hline & 2 y $9 \mathrm{~m}$ & $\begin{array}{l}7 \text { weeks stay in a paediatric clinic with daily } 400 \mathrm{kcal} \\
\text { caloric restriction }\end{array}$ & $-4 \mathrm{~kg}(-12.05 \%)$ \\
\hline & 3 y $10 \mathrm{~m}$ & 1.5 years outpatient psychotherapy & None \\
\hline & 5 y $6 \mathrm{~m}$ & 1 year inpatient psychotherapy ${ }^{c}$ & $-14 \mathrm{~kg}(-29.79 \%)$, followed by slow weight regain \\
\hline & 6 y 5 m & 3 years outpatient psychotherapy & None \\
\hline & 9 y $5 \mathrm{~m}$ & $\begin{array}{l}3 \text { years growth hormone treatment due to short stature } \\
\text { and growth hormone deficiency }\end{array}$ & $+59 \mathrm{~kg}(+38.8 \%)$ \\
\hline & 12 y 7 m & $\begin{array}{l}4 \text { months stay in a rehabilitation clinic with obesity } \\
\text { long-term therapy }{ }^{d}\end{array}$ & $+4 \mathrm{~kg}(+4.0 \%)$ \\
\hline & 12 y $11 \mathrm{~m}$ & $\begin{array}{l}\text { Regular advice and support from the youth welfare } \\
\text { department, psychological care and medical weight } \\
\text { control }\end{array}$ & None \\
\hline & 14 y 3 m & Bariatric surgery: gastric banding ${ }^{\mathrm{e}}$ & $-49 \mathrm{~kg}(-33.84 \%)$ \\
\hline & 14 y $4 \mathrm{~m}$ & $\begin{array}{l}28 \text { days stay in a child and adolescent psychiatry after } \\
\text { gastric banding }\end{array}$ & $-5 \mathrm{~kg}(-3.72 \%)$ \\
\hline & 25 y $0 \mathrm{~m}$ & Removal of gastric banding due to band migration ${ }^{f}$ & $+15 \mathrm{~kg}(+14.8 \%)$ within 4 years \\
\hline
\end{tabular}

${ }^{\mathrm{a}-\mathrm{f}}$ Refer to Fig. 1 and display the time points of interventions and their impact on weight

isolated from leucocytes. Subsequently, the DNA was amplified by polymerase chain reaction for all coding exons from the leptin receptor (LEPR) gene and then sequenced by Sanger method. The available sequence data were compared with the common LEPR reference sequence (NM_002303.4). The results show that compound heterozygous variants in the $L E P R$ gene are the cause for the severe early-onset obesity in both patients. Patient 1 has a splice site/frameshift deletion (c.2598-3_2607delTAGAATGAAAAAG) as well as a missense mutation (c.2227 T>C [p.Ser743Pro]). Patient 2 carries the missense mutations c.1874G $>$ A [p.His684Pro] and c.2051A $>$ C [p.Trp625\%]. These changes in the LEPR gene result in both patients in a premature termination of the protein biosynthesis and a loss of LEPR function.

Disruptions in the leptin-melanocortin signalling pathway have far-reaching consequences for the regulation of hunger, satiety, and body weight $[4,9]$. The hormone leptin is secreted by the adipose tissue and reflects the energy stores of the body. Leptin crosses the blood-brain barrier and activates LEPR in the hypothalamus, initiating a complex signalling cascade. Consequently, leptin inhibits the production of the neuropeptide $\mathrm{Y}$ and agouti-related peptide in orexigenic neurons, while stimulating the proopiomelanocortin (POMC) synthesis in anorexigenic POMC neurons. POMC is then 
Table 3 Clinical and laboratory findings at the time of diagnosis

\begin{tabular}{|c|c|c|c|c|}
\hline \multirow{2}{*}{ Age } & & \multirow{2}{*}{$\begin{array}{l}\text { Patient } 1 \\
20 \text { years }\end{array}$} & \multirow{2}{*}{$\begin{array}{l}\text { Patient } 2 \\
29 \text { years }\end{array}$} & \multirow[t]{2}{*}{ Reference range } \\
\hline & & & & \\
\hline Weight & $\mathrm{kg}$ & 172 & 120.5 & \\
\hline Height & $\mathrm{m}$ & 1.66 & 1.70 & \\
\hline BMI & $\mathrm{kg} / \mathrm{m}^{2}$ & 62.1 & 41.6 & \\
\hline BMI SDS & & 3.64 & 3.07 & \\
\hline Blood pressure & $\mathrm{mmHG}$ & $121 / 85$ & $137 / 86$ & \\
\hline Pubertal stage by Tanner & & $\mathrm{PH}, 5 ; \mathrm{B}, 5$ & $\mathrm{PH}, 6$; testicular volume, $16 \mathrm{ml}$ and $14 \mathrm{ml}$ & \\
\hline Insulin-like growth factor 1 & $\mathrm{ng} / \mathrm{ml}$ & 231 & 182 & f, 122-384; m, 117-321 \\
\hline Leptin & $\mu \mathrm{g} / \mathrm{l}$ & 34.4 & 12.5 & $3.6-11.1$ \\
\hline Total cholesterol & $\mathrm{mmol} / \mathrm{l}$ & 4.3 & 3.8 & $<5.0$ \\
\hline LDL cholesterol & $\mathrm{mmol} / \mathrm{l}$ & 3.2 & 2.3 & $>1.0$ \\
\hline HDL cholesterol & $\mathrm{mmol} / \mathrm{l}$ & 0.5 & 1.2 & $<3.0$ \\
\hline Thyreotropin & MIU/I & 2.02 & 1.88 & $12.8-20.4$ \\
\hline Free thyroxine & $\mathrm{pmol} / \mathrm{l}$ & 11.7 & 19 & $3.13-6.76$ \\
\hline Testosterone & $\mu \mathrm{g} / \mathrm{l}$ & 0.19 & 4.25 & $f, 0.084-0.481 ; m, 2.490-8.360$ \\
\hline
\end{tabular}

$B M I$ body mass index, BMI SDS body mass index standard deviation score, $f$ female, $L D L$ low-density lipoprotein, $H D L$ high-density lipoprotein, $m$ male

processed via prohormone convertase 1 into the $\alpha$ melanocyte-stimulating hormone $(\alpha-\mathrm{MSH})$, which activates the melanocortin 4 receptor (MC4R). This finally mediates a feeling of satiety, reduces food intake, and enhances energy expenditure [10-12]. In summary, the disease-causing variants in the LEPR gene found in the two patients interrupt the leptin-melanocortin signalling pathway and lead to severe early-onset obesity, pronounced hyperphagia, and permanent food-seeking behaviour.

\section{Treatment}

The finding of the causative molecular diagnosis meant a great relief to the patients and their families. However, so far, there is no standardised causal treatment option for patients with disease-causing variants in the $L E P R$ gene. Both patients could not achieve weight control by a balanced, calorie-reduced diet with increased physical activity. Recently, a first causal pharmacological treatment has been described [8] and is currently being evaluated in the phase III trial RM-493-015 and the extension trial RM-493-022. Both patients were enrolled in these clinical studies and started the treatment with the new MC4R agonist setmelanotide. Setmelanotide affects the leptin-melanocortin signalling pathway and thus the regulation of hunger and satiety by substituting the missing endogenous $\alpha-\mathrm{MSH}$. It activates the MC4R and induces a feeling of satiety, reduces food intake, and finally leads to a significant weight reduction in patients with LEPR deficiency [8].

\section{Discussion}

The two case reports describe the frustrating diagnostic and therapeutic history of two patients with diseasecausing, compound heterozygous variants in the LEPR gene. Comparable with the previous published $88 \mathrm{pa}$ tients with LEPR deficiency, our patients show extreme early-onset obesity, pronounced hyperphagia, and hypogonadotropic hypogonadism $[9,13]$. Moreover, we observed a severe psychological strain in our patients, including stigmatisation, social isolation, and severe accusations. Patients with monogenic obesity and their families require specialised care as well as comprehensive and lasting support to deal with the numerous challenges and consequences of this disease $[2,14]$.

It is therefore highly recommended to perform early, extensive diagnostic, including a molecular genetic testing in children with extreme obesity to provide them with the necessary support and therapy as early as possible [5, 12]. Genetic examinations for variants in the leptin gene and $L E P R$ gene are particularly indicated for children at the age of 2 years with BMI $\geq 27 \mathrm{~kg} / \mathrm{m}^{2}$ or at the age of 5 years with BMI $\geq 33 \mathrm{~kg} / \mathrm{m}^{2}$. In addition, in children with BMI > 99.5 age- and sex-adjusted percentile, and normal weight parents or hyperphagic eating behaviour, a genetic investigation for other monogenic variations causing obesity should be carried out [15].

The main objective in the treatment of patients with monogenic obesity is to control body weight. This should primarily be achieved through a balanced, energy-reduced, controlled diet while increasing physical activity. Our case reports show however that 
behavioural-based treatment programmes in specialised obesity clinics neither in an outpatient nor in an inpatient setting contributed to weight control. On the contrary, they lead to frustration and disappointment. Bariatric surgery also did not result in long-term success of weight loss and weight maintenance in our patients comparable to three other published case reports of patients with LEPR deficiency and bariatric surgery $[16,17]$. To date, only one patient with LEPR deficiency was able to reduce his weight in the long term due to bariatric surgery [18]. Currently, the evidence for the efficacy of bariatric surgery is limited in patients with LEPR deficiency and other monogenic obesity disorders. Therefore, bariatric surgeries should only be conducted in patients with monogenic obesity after a critical risk-benefit analysis and after the exhaustion of the existing non-invasive, conservative, and pharmacological treatment options $[19,20]$. In order to avoid unsatisfactory bariatric therapies, genetic testing should be performed in patients with hints for monogenic obesity to exclude monogenic causes for obesity preoperatively. This especially includes severely obese patients whose weight development in early childhood is striking and whose BMI exceeded $27 \mathrm{~kg} / \mathrm{m}^{2}$ at the age of 2 years and $33 \mathrm{~kg} / \mathrm{m}^{2}$ at the age of 5 years [15]. The onset of obesity at school age is less frequently associated with monogenic obesity [15].

The surprising disappearance of hypogonadotropic hypogonadism could probably be attributed to the postoperative initial weight loss after bariatric surgery in our patients, as well as in two other patients with LEPR deficiency $[16,18]$. However, there are also reports of spontaneous puberty in patients with LEPR deficiency without surgery. Furthermore, a gender-specific effect on reproduction is currently discussed in patients with LEPR deficiency [21].

So far, only individual pharmacological treatment approaches such as off-label use of methylphenidate provided the possibility to support weight control in addition to conventional therapies containing strict nutritional and exercise control [7]. However, a first causal treatment option with the MC4R agonist setmelanotide is recently available in the context of clinical studies for certain patients with monogenic obesity. The first results of patients with LEPR deficiency under setmelanotide treatment showed significant reductions in body weight and hyperphagia with only mild adverse events [8]. Thus, setmelanotide currently offers a promising causal treatment option for certain patients with monogenic obesity.

\section{Lessons learned and specific recommendations}

Case reports on rare genetic diseases as demonstrated in our paper are important to improve knowledge and to derive specific recommendations for the clinic.
Therefore, we summarise the lessons learned from the two patients with LEPR deficiency and provide some recommendations for diagnosis and treatment of patients with suspected monogenic obesity, especially for patients with LEPR deficiency.

Severely obese patients should receive genetic diagnostic as early as possible if they show suspicious weight development in early childhood [15]. If no genetic cause for the extreme obesity can be found in a molecular genetic obesity panel analysing all currently established genes causative for monogenic obesity, further genetic diagnostics should be performed. It is possible to find new or further causes for genetic obesity using microarray-based comparative genomic hybridization, methylation-specific multiplex ligation-dependent probe amplification, or whole exome sequencing of the patient and parents (trio analysis).

After diagnosis of monogenic obesity, e.g. LEPR deficiency, further diagnostic examinations to find the cause of obesity are dispensable. If a genetic cause of obesity has been diagnosed, further examinations related to comorbidities should be carried out according to the recent guidelines [22]. The screening for comorbidities in paediatric obesity should include the screening for diabetes mellitus, dyslipidaemia, hypertension, nonalcoholic fatty liver disease, obstructive sleep apnea, etc. [22].

There are causal pharmacological treatment options for some forms of monogenic obesity, e.g. patients with leptin deficiency can be successfully treated with metreleptin [6]. In the future, one or more drugs targeting the leptin-melanocortin signalling pathway will be available to treat patients with LEPR deficiency and POMC deficiency $[8,23]$.

A specific and individually tailored follow-up and support plan is recommended for patients with genetic obesity without causal therapy or extremely obese patients with negative finding of genetic obesity after extensive molecular genetic diagnostics. All specialists involved in the treatment should be aware that patients with diagnosed monogenic obesity are exposed to a strong biological basis that commonly causes the onset of obesity in early childhood. Therefore, it should be avoided to blame the patient or family for the extreme weight gain. Furthermore, psychological support should be a priority in the individual follow-up and support plan of these patients. Psychologist should primarily help and support patients and parents to deal with stigmatisation and discrimination in the social environment and in the public health sector. In addition, it is essential to provide a healthy and restricted diet as well as daily physical activity. Training programmes focusing on positive feedback can be helpful in achieving daily physical activity and increasing self-empowerment, self- 
confidence, and general well-being. Specialists involved in treatment should ensure that the support programmes offered to the family are individually tailored to the requirements of the patient and family. Unrealistic treatment goals must be avoided in patients with monogenic obesity particularly with regard to weight reduction. Patients with monogenic obesity and currently no causal pharmacological treatment option may be treated with an off-label use of methylphenidate and dextroamphetamine to support weight control and prevent further weight gain [7, 24]. Additionally, the involvement of a social worker can support the patient and family at home to deal with the daily challenges associated with this disease and the extreme obesity. Those specialists can provide diverse socio-medical assistance based on the new International Classification of Functioning, Disability and Health (ICF) core set for obesity. The ICF core set defines the spectrum of symptoms and problems in functioning of persons with obesity. On this basis, obese patients in some countries can receive government support to encourage social participation of extremely obese children and their parents [2].

\section{Conclusion}

These two case reports illustrate the urgent necessity for early molecular genetic diagnostics in patients with severe, early-onset obesity to avoid lengthy diagnostic and unsuccessful and frustrating therapeutic procedures. A BMI $>27 \mathrm{~kg} / \mathrm{m}^{2}$ at the age of 2 years indicates causative biallelic variants in the genes encoding leptin or leptin receptor. In addition, a BMI > 99.5 age- and genderadjusted percentile and pronounced hyperphagia indicate a monogenic disease. Particularly, in these patients, genetic testing is highly recommended. Furthermore, it is advisable to perform genetic testing before bariatric procedures in young patients with early-onset, severe obesity who might carry a causative genetic variant to avoid unsatisfactory results in such patients. After the diagnosis of monogenetic obesity, it is very important that patients are seen by specialists to monitor weight and comorbidities and to obtain the necessary therapeutic and psychological support. In the future, causal pharmacological therapies will be available for patients with different forms of monogenic obesity.

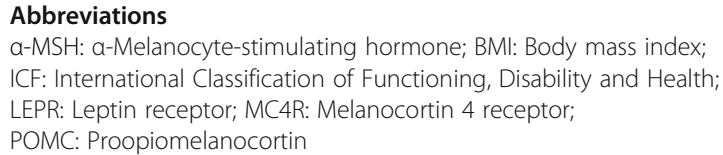

\section{Acknowledgements}

Not applicable.

\section{Authors' contributions}

SZ and MW collected and analysed the data and wrote the manuscript. JvS and KK collected the patient's data and reviewed/edited the manuscript. CD reviewed/edited the manuscript. All authors had final approval of the submitted and published version.

\section{Authors' information}

Not applicable.

\section{Funding}

No funding was received for this research project. Open Access funding enabled and organized by Projekt DEAL.

\section{Availability of data and materials}

The datasets generated and analysed during the current case report are available from the corresponding author on reasonable request.

\section{Ethics approval and consent to participate}

Not applicable.

\section{Consent for publication}

Written informed consent for publication of their clinical details was obtained from the patients.

\section{Competing interests}

The Division of Pediatric Endocrinology and Diabetes at UIm University Medical Center participated as a study centre in the therapy studies RM-493014 and RM-493-022 funded by Rhythm Pharmaceuticals Inc. All authors are part of the study team.

Received: 24 August 2020 Accepted: 29 September 2020

Published online: 03 November 2020

\section{References}

1. Robert Koch-Institut (2018) Overweight and obesity among children and adolescents in Germany. Results of the cross-sectional KiGGS Wave 2 study and trends. https://doi.org/10.17886/RKI-GBE-2018-022

2. Siebert MF, Baumann A, Wabitsch M (2020) Federal act on participation: opportunities for people with severe obesity. Dtsch Med Wochenschr 145: 863-867. https://doi.org/10.1055/a-1146-1180

3. Montague CT, Farooqi IS, Whitehead JP, et al (1997) Congenital leptin deficiency is associated with severe early-onset obesity in humans. Nature 387:903-908. https://doi.org/https://doi.org/10.1038/43185

4. Clément K, Vaisse C, Lahlou N, et al (1998) A mutation in the human leptin receptor gene causes obesity and pituitary dysfunction. Nature 392:398-401. https://doi.org/10.1038/32911

5. Huvenne H, Dubern B, Clément K, Poitou C (2016) Rare genetic forms of obesity: clinical approach and current treatments in 2016. Obes Facts 9:158173. https://doi.org/10.1159/000445061

6. Farooqi IS, Jebb SA, Langmack G, et al (1999) Effects of recombinant leptin therapy in a child with congenital leptin deficiency. N Engl J Med 341:879884. https://doi.org/10.1056/NEJM199909163411204

7. Brandt S, Schnurbein J, Lennerz B, et al (2020) Methylphenidate in children with monogenic obesity due to LEPR or MC4R deficiency improves feeling of satiety and reduces BMI-SDS - a case series. Pediatric Obesity 15. https:// doi.org/10.1111/ijpo.12577

8. Clément K, Biebermann H, Farooqi IS, et al (2018) MC4R agonism promotes durable weight loss in patients with leptin receptor deficiency. Nat Med 24: 551-555. https://doi.org/10.1038/s41591-018-0015-9

9. Nunziata A, Funcke J-B, Borck G, et al (2019) Functional and phenotypic characteristics of human leptin receptor mutations. J Endoc Soc 3:27-41. https://doi.org/10.1210/js.2018-00123

10. Baldini G, Phelan KD (2019) The melanocortin pathway and control of appetite-progress and therapeutic implications. J Endocrinol 241:R1-R33. https://doi.org/10.1530/JOE-18-0596

11. Saeed S, Arslan M, Froguel P (2018) Genetics of obesity in consanguineous populations: toward precision medicine and the discovery of novel obesity genes: obesity and consanguinity. Obesity 26:474-484. https://doi.org/10. 1002/oby.22064

12. von Schnurbein J, Borck G, Hinney A, Wabitsch M (2018) Monogene Adipositas: Neue diagnostische und therapeutische Möglichkeiten. Monatsschr Kinderheilkd 166:388-394. https://doi.org/10.1007/s00112-018$0461-y$ 
13. Kleinendorst L, Abawi O, van der Kamp HJ, et al (2020) Leptin receptor deficiency: a systematic literature review and prevalence estimation based on population genetics. Eur J Endocrinol 182:47-56. https://doi.org/10.1530/ EJE-19-0678

14. Kleinendorst L, van Haelst MM, van den Akker ELT (2017) Young girl with severe early-onset obesity and hyperphagia. BMJ case reports bcr-2017221067. https://doi.org/10.1136/bcr-2017-221067

15. Kohlsdorf K, Nunziata A, Funcke J-B, et al (2018) Early childhood BM trajectories in monogenic obesity due to leptin, leptin receptor, and melanocortin 4 receptor deficiency. Int J Obes 42:1602-1609. https://doi. org/10.1038/s41366-018-0049-6

16. Nizard J, Dommergues M, Clément K (2012) Pregnancy in a woman with a leptin-receptor mutation. N Engl J Med 366:1064-1065. https://doi.org/10. 1056/NEJMC1200116

17. Huvenne H, Le Beyec J, Pépin D, et al (2015) Seven novel deleterious LEPR mutations found in early-onset obesity: a $\Delta$ exon6- 8 shared by subjects from Reunion Island, France, suggests a founder effect. J Clin Endocrinol Metab 100:E757-E766. https://doi.org/10.1210/jc.2015-1036

18. Le Beyec J, Cugnet-Anceau C, Pépin D, et al (2013) Homozygous leptin receptor mutation due to uniparental disomy of chromosome 1: response to bariatric surgery. J Clin Endocrinol Metab 98:E397-E402. https://doi.org/ 10.1210/jc.2012-2779

19. Vos N, Oussaada SM, Cooiman Ml, et al (2020) Bariatric surgery for monogenic non-syndromic and syndromic obesity disorders. Curr Diab Rep 20:44. https://doi.org/10.1007/s1 1892-020-01327-7

20. Cooiman Ml, Kleinendorst L, Aarts EO, et al (2020) Genetic obesity and bariatric surgery outcome in 1014 patients with morbid obesity. Obes Surg 30:470-477. https://doi.org/10.1007/s11695-019-04184-w

21. Dehghani MR, Mehrjardi MYV, Dilaver N, et al (2018) Potential role of gender specific effect of leptin receptor deficiency in an extended consanguineous family with severe early-onset obesity. Eur J Med Genet 61: 465-467. https://doi.org/10.1016/j.ejmg.2018.03.006

22. Styne DM, Arslanian SA, Connor EL, et al (2017) Pediatric obesity -assessment, treatment, and prevention: an Endocrine Society clinical practice guideline. J Clin Endocrinol Metab 102:709-757. https://doi. org/10.1210/jc.2016-2573

23. Kühnen $\mathrm{P}$, Clément $\mathrm{K}$, Wiegand $\mathrm{S}$, et al (2016) Proopiomelanocortin deficiency treated with a melanocortin-4 receptor agonist. N Engl J Med 375:240-246. https://doi.org/10.1056/NEJMoa1512693

24. Denzer C, Denzer F, Lennerz BS, et al (2019) Treatment of hypothalamic obesity with dextroamphetamine: a case series. Obes Facts 12:91-102. https://doi.org/10.1159/000495851

\section{Publisher's Note}

Springer Nature remains neutral with regard to jurisdictional claims in published maps and institutional affiliations.

\section{Submit your manuscript to a SpringerOpen ${ }^{\circ}$ journal and benefit from:}

- Convenient online submission

- Rigorous peer review

- Open access: articles freely available online

- High visibility within the field

- Retaining the copyright to your article

Submit your next manuscript at $\boldsymbol{\nabla}$ springeropen.com 